\title{
Estimation of bacterial number in the water, sediment and biofilm of Badek and Mewek River (Malang, Indonesia) using Plate Count and eDNA Method
}

\author{
DEVI ULINUHA ${ }^{1,2, \bullet}$, SRI ANDAYANI ${ }^{3}$, ASUS MAIZAR SURYANTO HERTIKA ${ }^{3, \vee \bullet}$, YUNI KILAWATI $^{3}$ \\ ${ }^{1}$ Doctoral Program in Fisheries and Marine Sciences, Faculty of Fisheries and Marine Sciences, Universitas Brawijaya. Jl. Veteran No.16, Malang 65145, \\ East Java, Indonesia. Tel./fax.: +62-341-553512, `email: devi.ulinuha@unud.ac.id. \\ ${ }^{2}$ Program of Aquatic Resource Management, Faculty of Marine Sciences and Fisheries, Universitas Udayana. Jl. Raya Kampus Unud Jimbaran, Badung \\ 80361, Bali, Indonesia \\ ${ }^{3}$ Faculty of Fisheries and Marine Sciences, Universitas Brawijaya. Jl. Veteran No.16, Malang 65145, East Java, Indonesia. Tel./fax.: +62-341-553512, \\ vemail: asusmaizar@yahoo.com
}

Manuscript received: 3 July 2020. Revision accepted: 28 July 2020.

\begin{abstract}
Ulinuha D, Andayani S, Hertika AMS, Kilawati Y. 2020. Estimation of bacterial number in the water, sediment, and biofilm of Badek and Mewek River (Malang, Indonesia) using Plate Count and eDNA Method. Biodiversitas 21: 3832-3836. Several methods have been developed to quantify bacterial numbers in the environment, but the studies is still continued to provide the most effective and efficient method. This study was aimed to compare the capacities of two different methods (Plate Count and eDNA Method) to estimate the bacterial number in the water, sediment, and biofilm of Badek and Mewek River (Malang-Indonesia). The Plate Count Method was carried out on a Plate Count Agar (PCA) which was incubated for 24 hours at $37^{\circ} \mathrm{C}$. The eDNA method was performed by slow agitation (1,800 rpm) to extract the environmental DNA of bacteria. Quantification of bacteria was obtained from the eDNA band intensity after electrophoresis in $1 \%$ gel agarose electrophoresis. Smartladder was used as a marker for the eDNA Method. The result showed that the eDNA Method was efficient for the estimation of bacterial numbers in the sediment and biofilm of Badek and Mewek River. However, this method was not suitable for estimating bacterial numbers in the water.
\end{abstract}

Keywords: Estimation, bacterial number, Plate Count Method, eDNA Method, River

\section{INTRODUCTION}

Several methods in microbiology have been developed tremendously in the last few decades. The most common microbiological methods have heightened awareness of the study on the bacteriology, such as the enumeration of environmental bacterial numbers. Studies on the enumeration of the bacterial number have expanded in various methods. The common methods used are Plate Count and Direct Counting Method. The Plate Count Method is limited to the quantitative estimation of cultivable bacteria (O'Toole 2016; Gensberger et al. 2016). Thus, the manual counting through this method is laborious and error-prone, even any method has been developed to automatically count the bacterial colonies (Brugger et al. 2012). Moreover, less than one percent of bacteria can grow in the culture media (Barer and Harwood 1999). This fact suggests a critical enumeration result in the Plate Count Method. In contrast, the Direct Counting Method leads to provide a more precise result since it directly counts the bacterial cells. However, this method needs more intricate steps (staining and microscope observation) during the application. Common staining dye used in this method is Acridine Orange (3,6bis(dimethylamino)acridinium chloride) and DAPI (4',6Diamidino-2-Phenylindole, Dihydrochloride) (Neeraja et al. 2017; Muthukrishnan et al. 2017).
To resolve this problem, Aoshima et al. (2006) introduced an alternative method for estimating the bacterial number in the environment based on their environmental DNA (eDNA) biomass. This method used a slow stirring agitation to minimize the DNA damage during the extraction. Quantification of bacterial numbers is carried out by using the mass of extracted eDNA. This provides an easier way to quantify the bacterial number compared to the direct counting method. The eDNA Method shows a strong correlation to the Direct Counting Method using DAPI staining. Therefore, the eDNA method can be used to estimate bacterial numbers from various samples collected from the environment, including the aquatic environments. This method successfully estimates the bacterial number in agricultural soils (Kai et al. 2015; Adhikari et al. 2016), but its capacity to enumerate the bacterial number in the aquatic environment (water, sediment, and biofilm) still needs to be evaluated. Therefore this study is purposed to evaluate the eDNA method to estimate the bacterial number in the water, sediment, and biofilm from aquatic environment, such as river ecosystem. It may provide more efficient method to quantify environmental bacteria compared to conventional methods.

Several rivers and streams are known to flows in Malang, East Java, Indonesia. These rivers flow from the upstream area (Batu region) to the lower area in the Malang 
region. A study carried out by Yetti et al. (2011) showed that several rivers in the Malang were at a moderate contamination level. Badek and Mewek Rivers are rivers in the downtown of Malang which might be influenced by their anthropogenic activities. River contamination can be neutralized through the mechanism of self-purification that involves the role of bacteria to reduce the contaminants in the river. These bacteria play an important role in the decomposition of organic matter and the reduction of several contaminants such as hydrocarbons and heavy metals (Viswanathan et al. 2015; Sanjay et al. 2020). These bacteria exist in the form of planktonic in the water, buried in the sediment, and biofilm consortium. Therefore, it is necessary to enumerate the number of bacteria from water, sediments, and biofilms in the Badek and Mewek River. Enumeration needs to be carried out not only on the cultivable bacterial cells, but also on the uncultivable bacteria that exist in the environment of Badek and Mewek River.

\section{MATERIALS AND METHODS}

\section{Study area}

This study was conducted in the Badek and Mewek River, Malang City, East Java Province, Indonesia. Water, sediment, and biofilm samples were collected from the Badek River (SB1, SB2, and SB3) and the Mewek River (SM1, SM2, and SM3) (Figure 1). Water sampling was carried out by using water sampler, and sediment sampling using Ekman grab. Biofilm (4 g) was collected from the surface of the indigenous stone by scrapping it with a toothbrush and mixed to sterile water $(12 \mathrm{~g})$ to provide $16 \mathrm{~g}$ of biofilm solution (4-time dilutions). All of the samples were kept in $4^{\circ} \mathrm{C}$ before analysis.

\section{Procedures}

Enumeration of the bacterial number using Plate Count Method

The bacterial number was counted on the Plate Count Agar (PCA) media (HIMEDIA, Netherland). The PCA media were prepared by mixing a $23.5 \mathrm{~g}$ of PCA media with $1 \mathrm{~L}$ of distilled water. Twenty $\mathrm{ml}$ of sterilized PCA was placed on a sterilized petri dish and allowed to solidify in room temperature $\left(25^{\circ} \mathrm{C}\right)$. Water samples were diluted 1,000 times before the analysis, while sedimentary and biofilm samples were diluted 10,000 times. The spread plate technique was carried out to culture the bacteria from the sample, then incubated at $37^{\circ} \mathrm{C}$ for 24 hours. Bacterial colonies grow on the media were counted by using a handy counter.
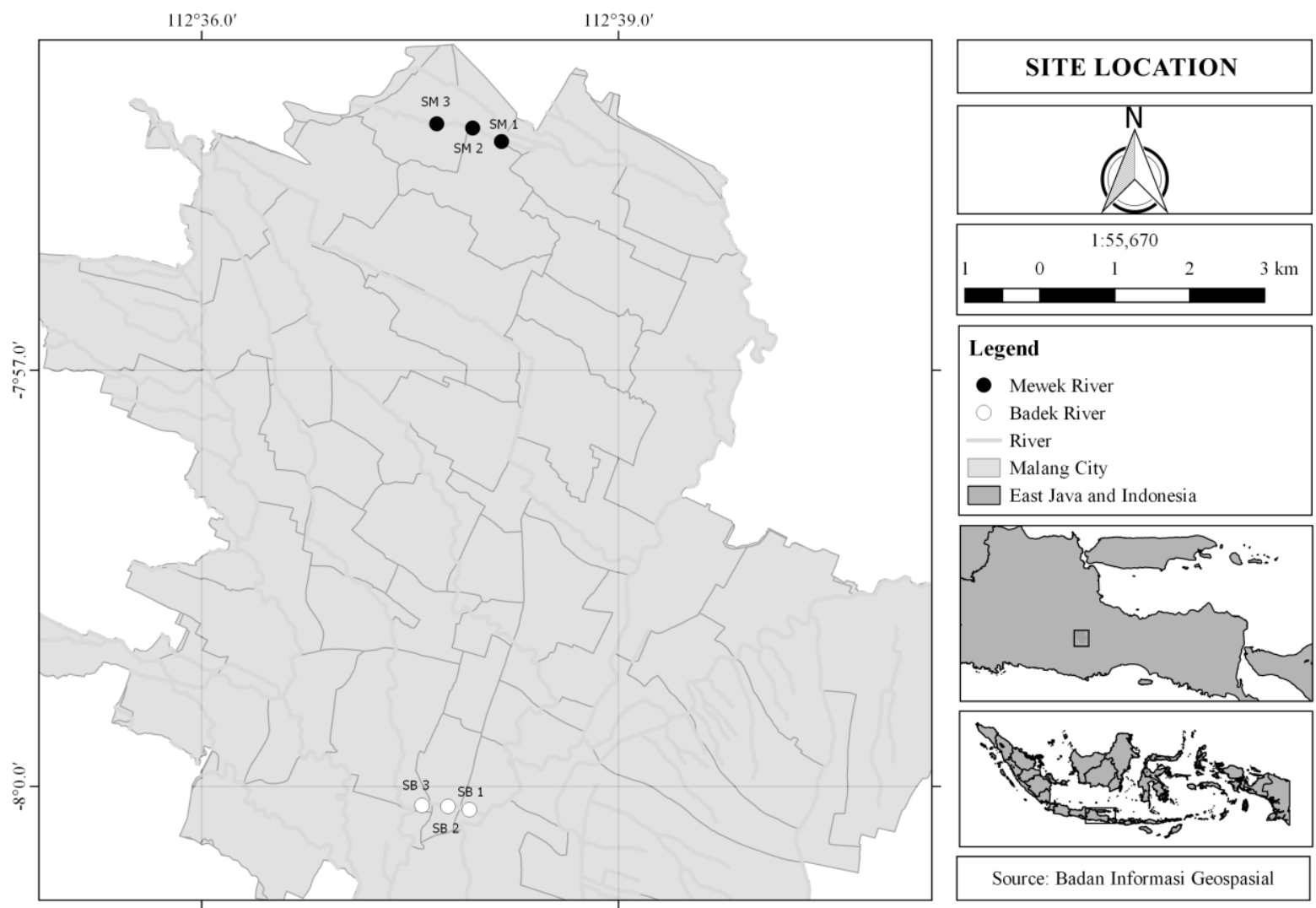

Figure 1. Site location of Badek and Mewek River, Malang City, East Java, Indonesia 


\section{Estimation of the bacterial number using eDNA Method}

Estimation of bacterial number (eDNA Method) was carried out by extracting eDNA (Aoshima et al. 2006). Each sample $(1 \mathrm{~mL}$ of water, $1 \mathrm{~g}$ of sediment, or $1 \mathrm{~g}$ of biofilm solution) was mixed with DNA extraction buffer ( 8 $\mathrm{ml}$ ) containing $100 \mathrm{mmol} / \mathrm{L}$ tris-hydroxymethyl aminomethane, $100 \mathrm{mmol} / \mathrm{L}$ sodium EDTA, $100 \mathrm{mmol} / \mathrm{L}$ sodium phosphate, $1.5 \mathrm{mmol} / \mathrm{L} \quad \mathrm{NaCl}, \quad 1 \%$ hexadecyltrimethylammonium bromide and $1.0 \mathrm{~mL} 20 \%$ (w/v) sodium dodecyl sulfate (SDS) solution. The mixture was stirred at low speed $(1800 \mathrm{rpm})$ for 20 minutes to separate the nucleic acid from its crude materials. The suspension was centrifuged at $6,000 \times \mathrm{g}$ for 10 minutes. The supernatant $(700 \mu \mathrm{L})$ was placed in a new $1.5 \mathrm{ml}$ microtube, and added with $700 \mu \mathrm{L}$ of the chloroformisoamyl alcohol mixture (24: 1) (v/v). The mixture was cooled-centrifuged at $18,000 \times \mathrm{g}$ for 10 minutes. The aqueous phase $(500 \mu \mathrm{L})$ was taken from the microtube and mixed with $300 \mu \mathrm{l}$ isopropanol. The nucleic acid was precipitated by centrifuging the mixture at $18,000 \times \mathrm{g}$ for 20 minutes. Pellet was rinsed with $1 \mathrm{ml}$ of $70 \%$ ethanol and dissolved in $50 \mu \mathrm{l}$ of TE buffer (Tris/EDTA $=10: 1$ $\mathrm{mmol} / \mathrm{L}$ ). The extracted eDNA was quantified based on the intensity of eDNA bands at $1 \%$ agarose gel. The extracted DNA was loaded at $5 \mu \mathrm{L}$ mixed with $3 \mu \mathrm{L}$ of $3 \times$ DNA Loading Dye. Smart Ladder (200-10,000 bp) was used as the eDNA band marker. The amount of eDNA and bacterial number was quantified using KODAK 1D 3.5 Imaging Software.

Comparison of Plate Count and eDNA Method to quantify water, sediment, and biofilm sample

The comparison of bacterial number that was estimated by using Plate Count Method and eDNA Method was presented in a simple line chart. This chart was allowed to observe the different bacterial numbers in the water, sediment, and biofilm by using Plate Count and eDNA Method.

\section{RESULTS AND DISCUSSION}

\section{Bacterial number in the water, sediment, and biofilm using Total Plate Count method}

The results showed that bacterial numbers in the water of Mewek and Badek River were ranging from 1.1 to 1.2 $\times 10^{5} \mathrm{CFU} / \mathrm{ml}$, and $0.9-1.1 \times 10^{5} \mathrm{CFU} / \mathrm{ml}$, respectively. The number of bacteria in the sediment of Mewek and Badek River were ranging from 2.1 to $2.2 \times 10^{6} \mathrm{CFU} / \mathrm{g}$, and 1.6$1.8 \times 10^{6} \mathrm{CFU} / \mathrm{g}$, respectively, while the bacterial number in the biofilm from Mewek and Badek River were ranging from 5.9 to $8.5 \times 10^{6} \mathrm{CFU} / \mathrm{g}$, and 4.2 to $6.6 \times 10^{6} \mathrm{CFU} / \mathrm{g}$. These results indicate that the bacterial number in the Badek River is lower than in the Mewek River (Table 1). It might be due to contamination by the tanning industry in the Badek River. A high amount of CrVI in water indicates high environmental pressure caused by the tanning activity (Kurniawan et al. 2019), resulting in environmental degradation and a reduction in the number of bacteria in the water.

\section{Bacterial number in the water, sediment and biofilm using eDNA Method}

Bacterial eDNA extraction from water samples of Badek and Mewek River did not show any proper band during the gel agarose electrophoresis. There was a very thin band that appeared in the gel, but it was not appropriate to be quantified during analysis (Figure 2). The thin band on the agarose gel might be due to the low bacterial eDNA mass collected from the water. In contrast to the result of bacterial eDNA extraction from the water sample, extraction of bacterial eDNA from sediment and biofilm showed a clear band during the agarose gel electrophoresis. The band derived from biofilm samples on gel agarose appear to be thinner than that of sediment samples, indicating lower biomass value. It might be due to sample dilution during the sample preparation. According to Aoshima et al (2006), the high number of living bacterial cells is indicated by the high molecular weight of eDNA. Therefore, the clear and thick band of eDNA during the agarose gel electrophoresis indicates a high number of bacteria present in the sample.


Figure 2. Agarose gel electrophoresis of extracted eDNA from: A. Water, B. Sediment, C. Biofilm ( $4 \times$ dilutions) 
Table 1. Bacterial number in the water, sediment, and biofilm of Badek and Mewek River, Malang, Indonesia

\begin{tabular}{|c|c|c|c|c|c|c|c|c|}
\hline \multirow{2}{*}{ Sample } & \multicolumn{3}{|c|}{ Badek River } & \multirow{2}{*}{ Average } & \multicolumn{3}{|c|}{ Mewek River } & \multirow{2}{*}{ Average } \\
\hline & SB1 & SB2 & SB3 & & SM1 & SM2 & SM3 & \\
\hline Water $\left(\times 10^{5} \mathrm{CFU} / \mathrm{ml}\right)$ & 0.9 & 1.1 & 1.0 & 1.0 & 1.1 & 1.2 & 1.2 & 1.2 \\
\hline Sediment $\left(\times 10^{6} \mathrm{CFU} / \mathrm{g}\right)$ & 1.6 & 1.8 & 1.7 & 1.7 & 2.1 & 2.2 & 2.2 & 2.2 \\
\hline Biofilm $\left(\times 10^{6} \mathrm{CFU} / \mathrm{g}\right)$ & 4.2 & 6.3 & 6.6 & 5.7 & 5.9 & 8.5 & 8.5 & 7.6 \\
\hline
\end{tabular}

The eDNA method successfully extracted environmental bacterial DNA from sediment and biofilm. The bacterial eDNA extracted from the sediment sample of Badek River was ranging from 11.6 to $12.5 \mathrm{ng} / 5 \mu \mathrm{L}$ with the average value of $12.1 \mathrm{ng} / 5 \mu \mathrm{L}$, while the extracted bacterial eDNA from biofilm sample result in higher value (14.6 ng/5 $\mu \mathrm{L}$ ) (Table 2). A similar pattern of the result was obtained from bacterial eDNA in the sediment and biofilm sample from Mewek River. The result suggests that slow stirring can extract bacterial eDNA in sediment and biofilm samples. Advanced molecular analysis might be good to apply for bacterial eDNA from the sediment and biofilm sample. Perwira et al (2017) applied the eDNA method to enumerate bacterial numbers in a PVA sponge during the operation of the water remediation system. This method can be applied to the PCR-DGGE method to describe the bacterial community structure in aerobic and anaerobic columns.

The average number of bacteria in sediment and biofilm of Badek River was $3.7 \times 10^{8}$ cells $/ g$ and $11.1 \times 10^{8}$ cells $/ g$, respectively (Table 3 ). The average number of bacteria in sediment and biofilm of Mewek River was $4.5 \times 10^{8}$ cells $/ g$ and $13.1 \times 10^{8}$ cells/g, respectively. These results suggest that bacterial number in the biofilm is higher compared to that in the sediment. Biofilm is made of bacterial consortium that is attached to the Extracellular Polymeric Substances (EPS) (Hiraki et al. 2009). This bacterial consortium usually consists of diverse bacterial numbers and species. In contrast, bacteria in sediment are dominated bacteria in a free-living form (Mohit et al. 2014).
Therefore, it is not surprising that bacterial number in the biofilm is higher than that in the sediment.

\section{Comparison of Plate Count and eDNA Method}

The line chart showed that bacterial number in the sediment and biofilm analyzed by eDNA Method was higher than that in the Plate Count Method (Figure 3B and 3C). In contrast, the Plate Count Method showed higher bacterial number in the water than the eDNA Method (Figure 3A). This result suggests that eDNA Method was more precise to estimate the bacterial number in the sediment and biofilm. This might be due to the capacity of the eDNA method to extract the eDNA of uncultivated bacteria in the sediment and biofilm. Previous studies showed that less than one percent of bacteria could be cultivated in an agar medium (Barer and Harwood 1999). The combination of Cetyltrimethylammonium Bromide (CTAB) method, Salting Out method, and physical lysis can optimize eDNA extraction (Dairawan and Shetty 2020).

In contrast to the sediment and biofilm sample, estimation of the number of bacteria in the water sample based on the eDNA method cannot be carried out due to the very thin band in the agarose gel. This might be due to the small amount of bacterial eDNA extracted from the sample. According to Aoshima (2006), the low bacterial number and dead cells of bacteria provide a low molecular weight of eDNA. Air drying might be used to concentrate the eDNA extract, but long time air exposure may damage the DNA and reduce the result precision (Chen et al. 2010).

Table 2. Bacterial eDNA mass extracted from sediment and biofilm

\begin{tabular}{|c|c|c|c|c|c|c|c|c|}
\hline \multirow{2}{*}{ Sample } & \multicolumn{3}{|c|}{ Badek River } & \multirow{2}{*}{ Average } & \multicolumn{3}{|c|}{ Mewek River } & \multirow{2}{*}{ Average } \\
\hline & SB1 & SB2 & SB3 & & SM1 & SM2 & SM3 & \\
\hline Sediment $(\mathrm{ng} / 5 \mu \mathrm{L})$ & 12.2 & 11.6 & 12.5 & 12.1 & 14.1 & 16.1 & 13.4 & 14.6 \\
\hline Biofilm $(n g / 5 \mu \mathrm{L})$ & 9.2 & 8.7 & 7.9 & 10.8 & 8.9 & 12.7 & 10.5 & 10.7 \\
\hline
\end{tabular}

Table 3. Bacterial eDNA mass extracted from sediment and biofilm

\begin{tabular}{|c|c|c|c|c|c|c|c|c|}
\hline \multirow{2}{*}{ Sample } & \multicolumn{3}{|c|}{ Badek River } & \multirow{2}{*}{ Average } & \multicolumn{3}{|c|}{ Mewek River } & \multirow{2}{*}{ Average } \\
\hline & SB1 & SB2 & SB3 & & SM1 & SM2 & SM3 & \\
\hline Sediment $\left(\times 10^{8}\right.$ cells/g) & 3.7 & 3.5 & 3.8 & 3.7 & 4.3 & 4.9 & 4.1 & 4.5 \\
\hline Biofilm $\left(\times 10^{8}\right.$ cells $\left./ \mathrm{g}\right)$ & 11.2 & 10.6 & 11.5 & 11.1 & 14.2 & 12.4 & 12.9 & 13.1 \\
\hline
\end{tabular}




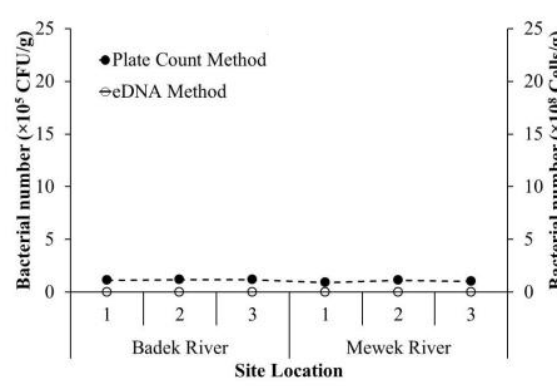

A

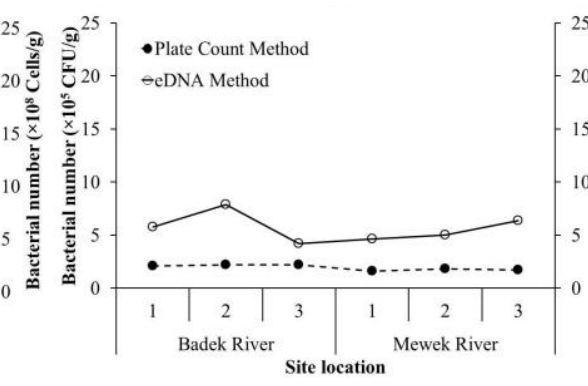

B

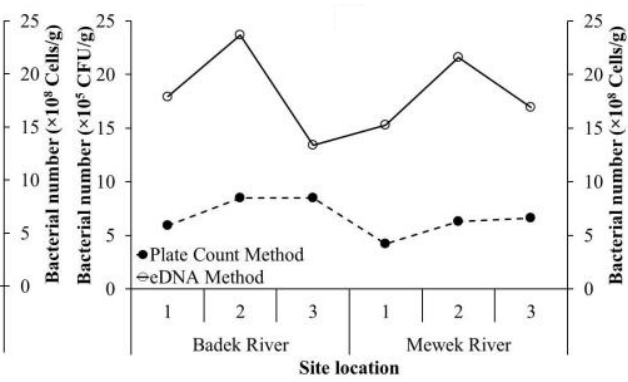

C

Figure 3. Estimation of bacterial number in the water (A), sediment (B), and biofilm (C) samples by Plate count and eDNA method

In conclusion, the slow stirring method is not efficient to extract the bacterial eDNA from the water sample of Badek and Mewek River. In contrast, the higher amount of bacterial number in the sediment and biofilm sample during eDNA analysis showed high efficiency of this method.

\section{ACKNOWLEDGEMENTS}

The authors gratefully thank the Ministry of Education and Culture for the support during the Doctoral Program at Faculty of Fisheries and Marine Science, Universitas Brawijaya, Malang, Indonesia. The authors also thank all lab members at Universitas Brawijaya and Universitas Udayana, Badung, Indonesia for conducting this research.

\section{REFERENCES}

Adhikari D, Mukai M, Kubota K, Kai T, Kaneko N, Araki KS, Kubo M. 2016. Degradation of Bioplastics in Soil and Their Degradation Effects on Environmental Microorganisms. J Agric Chem Environ 5 (1): 23-34

Aoshima H, Kimura A, Shibutani A, Okada C, Matsumiya Y, Kubo M. 2006. Evaluation of soil bacterial biomass using environmental DNA extracted by slow-stirring method. Appl Microbiol Biotechnol 71 (6): 875-80.

Barer MR, Harwood CR. 1999. Bacterial viability and culturability. Adv Microb Physiol 41: 93-137.

Brugger SD, Baumberger C, Jost M, Jenni W, Rugger U, Mühlemann K. 2012. Automated counting of bacterial colony forming units on agar plates. PloS ONE, 7 (3): e33695.

Chen H, Rangasamy M, Tan SY, Wang H, Siegfried BD. 2010. Evaluation of five methods for total DNA extraction from western corn rootworm beetles. PloS One 5 (8): e11963. DOI: 10.1371/journal.pone.0011963.
Dairawan M, Shetty PJ. 2020. The Evolution of DNA Extraction Methods. Ameri J Biomed Sci Res 8: 1. DOI: 10.34297/AJBSR.2020.08.001234.

Gensberger ET, Gőssl E-M, Antonielli L, Sessitsch A, Kostic T. 2016. Effect of different heterotrophic plate count methods on the estimation of the composition of the culturable microbial community. PeerJ 3 (1): e862. DOI: 10.7717/peerj.862.

Hiraki A, Tsuchiya Y, Fukuda Y, Yamamoto T, Kurniawan A, Morisaki H. 2009. Analysis of How a Biofilm Forms on the Surface of the Aquatic Macrophyte Phragmites australis. Microb Environ 24 (3): 265-272.

Kai T, Mukai M, Araki KS, Adhikari D, Kubo M. 2015. Physical and biochemical properties of Apple Orchard soils of different productivities. Open J Soil Sci 5 (7): 149-156.

Kurniawan A, Salamah LN, Jayati PD. 2019 Analysis of Cr(VI) pollution in the Badek River, Malang by using biofilm. Ecotrophic 13 (1): 1119. [Indonesian]

Neeraja M, Lakshmi V, Padmasri C, Padmaja K. 2017. Utility of Acridine Orange staining for detection of bacteria from positive blood cultures. J Microbiol Meth 139: 215-217.

Mohit V, Archambault P, Toupoint N, Lovejoy C. 2014. Phylogenetic Differences in Attached and Free-Living Bacterial Communities in a Temperate Coastal Lagoon during Summer, Revealed via HighThroughput 16S rRNA Gene Sequencing. Appl Environ Microbiol 80 (7): 2071-2083

Muthukrishnan T, Govender A, Dobretsov S, Abed RMM. 2017. Evaluating the reliability of counting bacteria using Epifluorescence Microscopy. J Mar Sci Eng 5 (1): 4.

O’Toole G.A. 2016. Classic spotlight: Plate counting you can count on. J Bacteriol 198 (23): 3127.

Perwira IY, Hanashiro T, Salamah LN, Adhikari D, Araki KS, Kubo M. 2017. Construction of a New Water Treatment System based on material circulation. J Water Resour Prot 9 (8): 1014-1025.

Viswanathan S, Anitha M, Amuthan M, Rajesh R, Veilumuthu P, Narayanan KR. 2015. Studies on the Role of Bacteria in Self Purification of the River Tamirabarani. Eur J Appl Sci 7 (1): 1-8.

Yetti E, Soedharma D, Haryadi S. 2011. Evaluation of river water quality in the Brantas River Basin Area of Malang related with the land use and its surrounding activities. Jurnal Pengelolaan Sumberdaya Alam dan Lingkungan 1 (1): 10-15. [Indonesian] 